\title{
HUBUNGAN PROFESIENSI BAHASA MELAYU DENGAN PENCAPAIAN AKADEMIK MURID BUKAN PENUTUR NATIF DI SEKOLAH JENIS KEBANGSAAN
}

\section{(The Relationship between Malay Language Proficiency and Academic Achievement among Non-native Students at National- Type School)}

Nora'Azian Nahar

noraazian@iium.edu.my

Kulliyyah Bahasa dan Pengurusan, Universiti Islam Antarabangsa Malaysia, Kampus Pagoh, Johor.

Terbit dalam talian (published online): 4 Disember 2020

Sila rujuk: Nora'Azian Nahar. (2020). Hubungan Profesiensi Bahasa Melayu dengan Pencapaian Akademik Murid Bukan Penutur Natif di Sekolah Jenis Kebangsaan. Jurnal Bahasa, 20(2), 287-316.

\begin{abstract}
Abstrak
Kelunturan penguasaan kemahiran berbahasa Melayu di Sekolah Jenis Kebangsaan (SJK) menyebabkan kemerosotan pencapaian akademik kebelakangan ini. Kajian dijalankan untuk mengenal pasti hubungan penguasaan keempat-empat kemahiran dalam bahasa Melayu dengan pencapaian prestasi akademik murid bukan penutur natif di Sekolah Jenis Kebangsaan (SJK). Seramai 414 orang sampel kajian dari lima buah sekolah SJK telah dipilih. Dua instrumen yang diguna pakai untuk mendapatkan data, iaitu Ujian Profesiensi UPBM_SR dan Tahap Skor UPBM_SR. Data diproses menggunakan IBMSPSS Versi 23 dengan reka bentuk tinjauan hirisan rentas. Hasil dapatan menunjukkan skor bagi keempat-empat ujian profesiensi yang telah dijalankan adalah pada peringkat sederhana. malah dapatan bagi kemahiran menulis adalah pada peringkat yang lemah. Keputusan bagi keseluruhan tahap profesiensi kemahiran mendengar, bertutur, membaca dan menulis secara majoriti murid mendapat Tahap 5 (hampir profesien), iaitu sebanyak 29\% (120 orang). Tiada murid yang mendapat Tahap 1 dan Tahap 8 . Hal ini
\end{abstract}


jelas menunjukkan bahawa perkaitan yang besar antara profesiensi bahasa Melayu dengan pencapaian akademik. Hanya murid yang cekap mendengar, fasih bertutur, lancar membaca dan mahir menulis terutama dalam bahasa kedua yang dapat meningkatkan pencapaian akademik mereka. Usaha yang padu daripada semua pihak diperlukan untuk melahirkan generasi yang kompeten dalam bahasa Melayu.

Kata kunci: bahasa kedua, kecekapan, lisan, murid bukan penutur natif, profesiensi

\begin{abstract}
The lack of mastery of Malay proficiency at National Type Schools (SJK) has caused deterioration of academic achievement in recent years. This study was conducted to determine the relationship of proficiency in all four skills of Malay language proficiency with students' academic achievement among non-native speakers at National Type Schools (SJK). A total of 414 samples from 5 SJK schools were selected for study. The two instruments used to obtain data are the UPBM_SR Proficiency Test and UPBM_SR Score Level. Data were processed using IBMSPSS Version 23 with a crosssectional survey design. The results show that the scores for the four Proficiency Tests conducted are moderate, and writing skills are at a low level. Results for the overall level of proficiency in listening, speaking, reading and writing skills showed that the majority of students obtained Level 5 (almost proficient), which is 29\% (120 students). No students received Level 1 or Level 8. This clearly shows that there is a great relationship between Malay language proficiency and academic achievement. Only students who are possess good listening, speaking, reading and writing skills in a second language are able to improve their academic performance. The diligent efforts of all parties are needed to create a generation competent in the Malay language.
\end{abstract}

Keywords: second language, competence, oral, non-native students, proficiency 


\section{PENGENALAN}

Tahap profesiensi seseorang murid diukur melalui kemampuan mereka berkomunikasi secara lisan, iaitu mendengar dan bertutur. Pendengar mendengar dengan teliti dan memahami maksud yang disampaikan dan memberikan respons dalam komunikasi. Murid yang menguasai kosa kata dapat menyebut perkataan dengan betul sekali gus dapat membaca dan mengaplikasikan perkara yang didengar, ditutur, dibaca dalam penulisan kerana keempat-empat kemahiran berlaku serentak. Dalam konteks bahasa kedua, pemerolehan hanya akan dicapai apabila bahasa kedua itu digunakan dalam komunikasi. Profesiensi berbahasa Melayu merupakan aspek yang memperlihatkan dengan lebih jelas perbezaan antara penutur natif dengan penutur bukan natif. Pengetahuan tentang aspek yang berkaitan dengan profesiensi berbahasa Melayu dikuasai oleh murid bukan penutur natif menerusi tatacara pemerolehan, iaitu dikuasai secara tidak formal dalam persekitaran keluarga, dan lebih merupakan sebahagian daripada sistem pendidikan (Ellis et al., 2008). Menurut Zulkifley (2014) pula, bagi murid bukan penutur natif, aspek profesiensi bahasa dikuasai menerusi pembelajaran formal di sekolah.

Keempat-empat kemahiran yang tersebut di atas saling bergantung antara satu sama lain seperti yang ditunjukkan dalam Rajah 1.

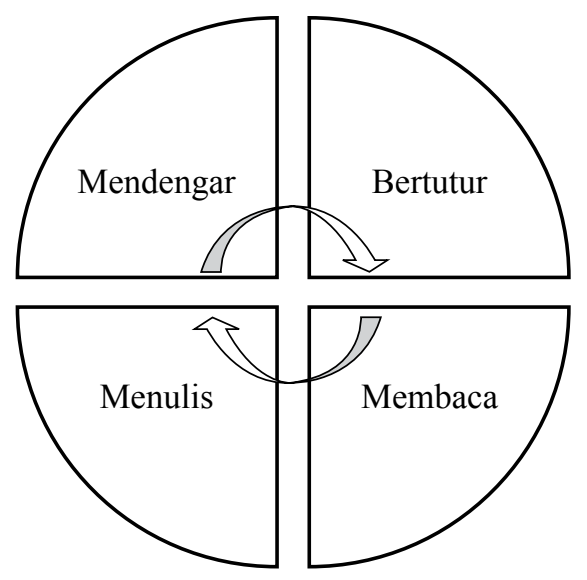

Rajah 1 Aspek profesiensi dalam penguasaan kemahiran berbahasa. (Adaptasi daripada Fadzilah dan Norazlina, 2015) 
Rajah 1 menunjukkan konsep penguasaan kemahiran bahasa dalam bahasa Melayu. Menurut Nora'azian, (2018) profesiensi berbahasa Melayu bermaksud murid berkebolehan mendengar secara aktif dalam pelbagai situasi dan mampu memberikan maklum balas membina terhadap perkara yang didengar. Profesiensi bertutur bermaksud penutur berkebolehan menyampaikan maklumat dengan sebutan, intonasi, penggunaan bahasa yang gramatis, dan bermakna semasa berkomunikasi. Keseluruhan pengucapan sangat petah, fasih dan lancar serta bertatasusila. Profesiensi membaca dapat diklasifikasikan sebagai kebolehan murid untuk membaca, memahami pelbagai bahan bacaan dengan lancar, berkemampuan memahami perkataan yang sukar dan kompleks. Murid lancar menaakul dan memindahkan maklumat pada tahap sangat terperinci dan konsisten. Profesiensi menulis pula, murid dapat menulis dan mengedit pada tahap yang paling tinggi, mampu menghasilkan penulisan kreatif pelbagai genre dengan menggunakan perkataan dan kosa kata yang pelbagai dan kompleks. Murid juga dapat menggunakan sistem bahasa dengan tepat pada tahap sangat terperinci dan konsisten. Mereka dapat menggunakan bahasa tersebut secara praktikal dengan penerapan teori linguistik di samping menggunakan sistem bahasa yang betul. Kemahiran tersebut digembleng untuk menentukan tahap kemahiran murid.

Keupayaan murid bukan penutur natif untuk mendapatkan gred yang baik bagi setiap mata pelajaran yang diuji dalam Peperiksaan Pertengahan Tahun bergantung pada tahap profesiensi mereka. Gred yang diperoleh menerusi peperiksaan bertulis melalui penilaian formatif dan sumatif. Set ujian rangsangan yang digunakan untuk mengukur pencapaian akademik murid dalam kajian ini ialah skor pencapaian BM-Penulisan, BMPemahaman dan peratus keseluruhan bagi enam subjek lain yang dijawab menggunakan bahasa pengantar di SJK sama ada bahasa Mandarin atau bahasa Tamil. Murid di SJK hanya menjawab soalan bahasa Melayu menggunakan bahasa Melayu. Dalam artikel ini pencapaian akademik bermaksud apa-apa yang dihasilkan atau diperoleh oleh seseorang murid dalam sesuatu pelajaran yang melibatkan pendidikan secara formal di sekolah. Perkaitan yang besar antara profesiensi dengan pencapaian akademik murid kerana kemampuan mendengar yang baik akan dapat membantu murid menghasilkan pertuturan yang baik dan seterusnya membantu menguasai kemahiran membaca dan menulis. Murid yang mempelajari bahasa Melayu sebagai bahasa kedua terpaksa mempelajari budaya berbahasa yang baharu, untuk meningkatkan pencapaian akademik di sekolah. 
Oleh itu, bagi mencapai aspirasi 90\% murid mendapat sekurangkurangnya gred kepujian dalam bahasa Melayu pada peringkat SPM, jurang prestasi antara kumpulan etnik perlu ditangani. Jurang ini mungkin berpunca daripada kurangnya pendedahan kepada bahasa Melayu semasa murid belajar di SJK. Sebanyak 96\% mata pelajaran bagi murid Cina dan $56 \%$ bagi murid India di SJK diajarkan dalam bahasa Cina dan bahasa Tamil masing-masing. Murid SJK mendapat kurang masa pengajaran dalam bahasa Melayu berbanding dengan murid di SK kerana mata pelajaran bahasa dibahagikan antara bahasa Melayu, Bahasa Inggeris, bahasa Cina atau bahasa Tamil. Bagi mengimbangi perbezaan ini, standard kurikulum dan pentaksiran Bahasa Melayu perlu dilaksanakan pada peringkat sekolah rendah bagi mengukur tahap profesiensi murid terutamanya di SJK. Oleh itu, pengujian yang sistematik dan bersepadu perlu dijalankan untuk meningkatkan kemahiran mendengar, bertutur, membaca dan menulis bagi mencapai aspirasi negara yang termaktub dalam Anjakan Kedua Pelan Pembangunan Pendidikan Malaysia PPPM (2013-2025).

Tahap profesiensi bagi keempat-empat kemahiran dalam berbahasa Melayu perlu diuji kepada murid di SJK untuk menyediakan suatu landasan ke arah kecemerlangan akademik di Malaysia. Kefasihan menggunakan bahasa kedua bagi murid SJK ini perlu dipraktikkan sejak awal usia kanak-kanak tersebut untuk membentuk kebiasaan kerana bahasa Melayu merupakan bahasa rasmi yang termaktub dalam Perlembagaan 152, dan Akta 1963 dan 1967 yang mengangkat bahasa Melayu sebagai bahasa kebangsaan di Malaysia.

\section{KAJIAN LEPAS}

Kajian berkaitan dengan bahasa asing atau bahasa kedua bagi kemahiran mendengar, bertutur, membaca dan menulis telah banyak dijalankan oleh penyelidik dari dalam dan luar negara. Antara kajian yang telah dijalankan adalah seperti yang berikut.

Kajian berkaitan dengan kemahiran mendengar telah dijalankan oleh Roshidah (2017). Sebanyak 68\% respondennya yang belajar bahasa Melayu di Institut National des Langues et Cilivisations Orientales (INALCO) Paris, melatih kemahiran mendengar dengan cara membaca transkrip sambil mendengar. Sebanyak $16 \%$ memilih gaya pembelajaran belajar bahasa Melayu dengan mendengar audio. Sebanyak 11\% pula tidak pasti memilih gaya pembelajaran semasa belajar bahasa Melayu. Seterusnya, sebanyak 5\% tidak mempunyai gaya pembelajaran tertentu 
untuk menguasai kemahiran mendengar. Kajian berkaitan dengan kemahiran lisan, iaitu kemahiran mendengar dan bertutur juga telah dijalankan oleh Zhang dan Goh (2006) di Universiti Singapura. Dapatan kajian menunjukkan daripada 40 strategi yang digunakan oleh 278 orang pelajar Melayu, Cina dan India yang belajar bahasa Inggeris sebagai bahasa kedua, hanya 13 strategi yang biasa digunakan untuk menguasai kemahiran tersebut.

Sumaiyah et al., (2018) juga menjalankan kajian bagi kemahiran mendengar dalam bahasa Arab. Pengkaji mendapati tahap pencapaian keseluruhan responden bagi kemahiran ini adalah pada tahap sederhana. Tahap pencapaian responden perempuan lebih tinggi berbanding dengan responden lelaki. Dapatan mereka menunjukkan bahawa terdapat dua faktor utama yang menghalang pencapaian kemahiran mendengar dalam mempelajari bahasa asing, iaitu faktor luaran dan faktor dalaman. Faktor luaran berkaitan dengan perkataan, kelajuan penutur, teks yang didengar, kekurangan bahan bantu belajar dan gangguan luar. Faktor dalaman disebabkan oleh sikap individu itu sendiri seperti bersikap negatif, mudah hilang tumpuan dan mengambil masa yang lama untuk faham. Dapatan utama kajian menunjukkan wujud beberapa masalah dalam aspek penguasaan kemahiran mendengar dalam bahasa Arab. Oleh yang demikian, disarankan siswa pendidik didedahkan dengan kepentingan penggunaan strategi kemahiran mendengar bahasa Arab.

Kajian berkaitan dengan kemahiran bertutur telah dijalankan oleh Awang (2011), terhadap pelajar Cina di universiti negara China. Dapatan kajiannya mendapati pengaruh bahasa ibunda yang kuat menyebabkan pelajar mengalami masalah dari segi sebutan dan tatabahasa semasa bertutur kerana terdapat perbezaan yang ketara antara bahasa Melayu dengan bahasa Cina. Punitha et al., (2017) juga telah menjalankan kajian tentang penguasaan kemahiran bertutur terhadap penutur asing dewasa dalam kalangan pelajar asing di Institusi Pendidikan Tinggi yang melibatkan golongan profesional. Tujuan kajian dijalankan untuk mengenal pasti strategi pembelajaran informal untuk mempelajari bahasa asing. Dapatan kajiannya mendapati pelajar bangsa asing dewasa cenderung menghafal kosa kata dan mengamalkan terjemahan langsung daripada bahasa jati masing-masing untuk melancarkan perbualan dalam bahasa kedua terutama bahasa Melayu.

Abdul Rasid, (2011), Hasnalee dan Zulkifley (2011), Chew, (2016), dan Wan Dyarudin et al., (2017) telah menjalankan kajian berkaitan dengan kemahiran membaca. Rumusan daripada dapatan kajian mereka 
menunjukkan masalah kemahiran membaca masih belum mencapai kejayaan. Dapatan kajian Hasnalee dan Zulkifley (2011), terhadap murid LINUS yang masih belum menguasai kemahiran membaca dan menulis berkait rapat dengan faktor persekitaran murid itu sendiri. Abdul Rasid, (2011) dan Chew (2016) juga mendapati murid bukan penutur natif di sekolah rendah, tidak dapat membunyikan perkataan dengan tepat dan betul. Mereka sering melakukan kesalahan sebutan fonem ( $m, n, t$, dan $r$ ). Keadaan ini sudah pasti mempengaruhi sebutan perkataan Melayu seperti "makan, mandi, mari, baru, lalu, durian, lari, lali". Selain itu, mereka juga menghadapi masalah dari segi sebutan konsonan bergabung seperti (sy, ny dan ng). Murid yang tidak menguasai asas dalam bacaan menyebabkan pencapaian akademik terutama bahasa Melayu kurang memuaskan. Ketidakupayaan murid menguasai kemahiran membaca pasti memberikan masalah kepada pelajar untuk menguasai kemahiran lanjut yang lain seperti mendengar, bertutur, dan menulis kerana murid kurang terdedah kepada bahasa Melayu dalam persekitaran kehidupan mereka. Wan Dyarudin et al., (2018) dalam pengajaran kefahaman membaca di sekolah menengah mencadangkan agar guru-guru menguasai teknik membaca SQ3R untuk mengajarkan bahasa.

Masalah utama yang dapat dikesan bagi kemahiran menulis dalam kalangan murid Tamil Tahap 1 di SJKT oleh Muhammad Saiful et al., (2012) ialah responden didapati sukar membezakan huruf. Mereka amat keliru dengan bentuk-bentuk huruf yang hampir sama seperti (n-m), (g-p) dan (c-e). Huruf terbalik (m-w), (n-u) dan huruf songsang (b-d), (q-p), dan (b-p). Masih ada responden yang tidak boleh menggabungkan suku kata, klausa, dan frasa untuk membentuk perkataan. Rata-rata responden tidak memahami struktur bahasa Melayu. Oleh itu, mereka menyusunnya sesuka hati tanpa mengira subjek atau predikat. Murid juga tidak memahami struktur ayat, dan tidak memahami pola ayat dalam bahasa kedua terutama bahasa Melayu. Noor Zila (2015) mendapati dalam situasi sebenar murid bukan penutur natif di SJKC, menghadapi masalah yang hampir sama, tidak dapat mengaplikasikan kemahiran menulis dalam bahasa Melayu. Pengajaran guru berfokuskan pemindahan fakta dan mengingat kembali untuk tujuan peperiksaan semata-mata. Kebanyakan murid akan menghafal rumus tatabahasa, karangan contoh dan menggunakan bahasa antara dalam penulisan mereka.

Pada peringkat sekolah menengah pula, dapatan kajian Noor Habsah, (2018) berkaitan dengan strategi pembelajaran kemahiran menulis bahasa Melayu sebagai bahasa kedua dalam kalangan pelajar Melanau 
menunjukkan tidak terdapat hubungan yang signifikan antara penggunaan strategi pembelajaran kemahiran menulis dengan pencapaian pelajar etnik Melanau dalam pelajaran bahasa Melayu. Dapatan ini membuktikan bahawa penggunaan strategi pembelajaran kemahiran menulis tidak boleh diukur berdasarkan pemilihan strategi pembelajaran semata-mata. Implikasi kajiannya juga menunjukkan bahawa pencapaian akademik pelajar etnik Melanau berada pada tahap sederhana. Namun begitu, bagi menjawab soalan peperiksaan awam di Malaysia pelajar perlu menguasai strategi pembelajaran yang disarankan seperti mengintegrasikan teknologi, contohnya internet, untuk mendedahkan mereka kepada pembelajaran bahasa selaras dengan kemahiran abad ke-21.

Dapat disimpulkan bahawa kajian tentang Tahap Keseluruhan Profesiensi Bahasa Melayu (TKPBM) bagi keempat-empat kemahiran kurang dilakukan di Malaysia. Kajian berkaitan dengan keseluruhan tahap bahasa Melayu bagi kemahiran mendengar, bertutur, membaca, dan menulis wajar dilakukan untuk melihat hubungan antara profesiensi bahasa Melayu dengan pencapaian akademik murid terutama di sekolah rendah kerana keempat-empat kemahiran tersebut berlaku serentak. Kekurangan ini perlu diisi untuk mendapatkan maklumat yang masih belum jelas dan terkini. Sampel kajian yang berbeza menghasilkan data kajian yang berbeza. Berdasarkan sorotan kajian, terdapat beberapa jurang penyelidikan yang ingin dirapatkan dan diselesaikan persoalannya.

\section{PERKAITAN ANTARA TEORI INPUT HIPOTESIS KRASHEN DENGAN PEMEROLEHAN DAN PEMBELAJARAN PROFESIENSI BAHASA KEDUA}

Teori Input Krashen (1985) didapati sesuai dengan keperluan kajian ini kerana berdasarkan teori yang dikemukakan di atas, penyelidik beranggapan bahawa kesemua hipotesis yang dibincangkan dapat diaplikasikan untuk melihat keberkesanan penguasaan bahasa kedua dari segi profesiensi (mendengar, bertutur, membaca dan menulis) bahasa Melayu dan hubungannya dengan pemboleh ubah yang dipilih dalam kalangan murid bukan penutur natif di sekolah rendah jenis kebangsaan.

Penggabungjalinan kelima-lima hipotesis dalam Teori Input Hipotesis Krashen ditunjukkan dalam Rajah 2. Tiga hipotesis, iaitu Hipotesis Pemerolehan dan Pembelajaran (1981), Hipotesis Dapatan (1981) dan Hipotesis Monitor (2007) dalam Krashen (2013) saling berkaitan dan 


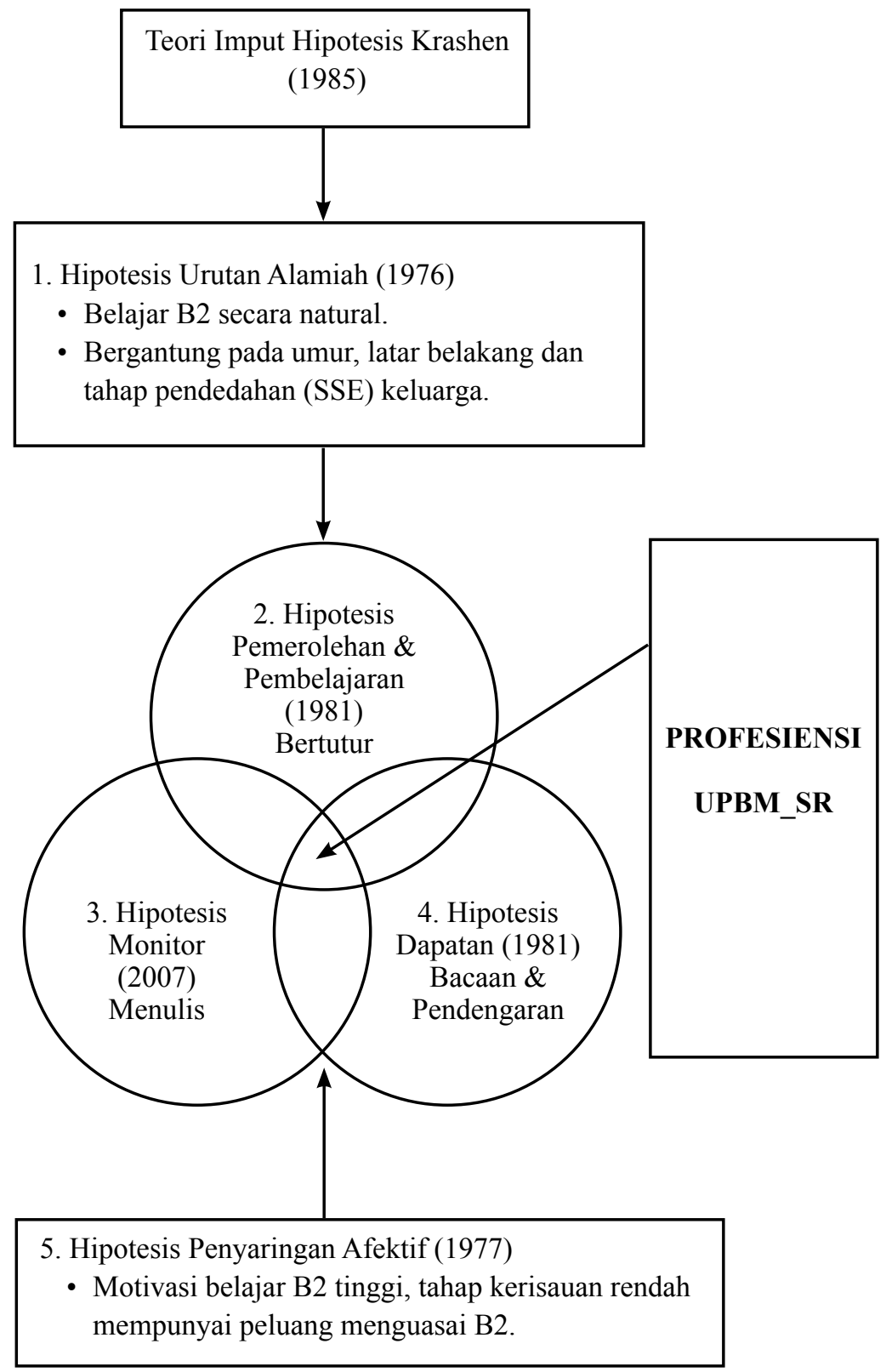

Rajah 2 Kerangka teoritikal. 
bertindanan antara satu sama lain. Kemahiran bertutur diperoleh secara pemerolehan tidak formal apabila murid berkomunikasi dalam bahasa kedua. Dapatan maklumat diperoleh melalui bacaan dan pendengaran. Bagi ayat yang kurang difahami dalam bahasa kedua, ayat tersebut akan dihafal untuk kemahiran menulis berdasarkan fungsi filter, organizer dan monitor. Daripada tindanan yang ditunjukkan dalam Rajah 2 jelas menunjukkan keempat-empat kemahiran dalam bahasa kedua saling berkaitan antara satu sama lain. Untuk mencapai tahap profesiensi paling tinggi murid bukan penutur natif perlu menguasai keempat-empat ujian, iaitu ujian mendengar, bertutur, membaca dan menulis dalam Ujian Profesiensi Bahasa Melayu Sekolah Rendah (UPBM_SR). Hipotesis pertama dan kelima merupakan faktor penentu kejayaan dalam pemerolehan bahasa kedua bagi murid bukan penutur natif. Penyelidik menguji kelima-lima hipotesis Teori Input Hipotesis Krashen (2005) dalam kajian ini.

\section{PERNYATAAN MASALAH}

Proses penguasaan kemahiran asas berbahasa seperti mendengar, bertutur, membaca dan menulis sering diabaikan dalam Pembelajaran dan Pemudahcaraan (PdPc) di dalam kelas. Keempat-empat kemahiran tersebut terutamanya kemahiran mendengar dan bertutur kurang diberikan perhatian oleh guru kerana memfokuskan latih tubi untuk menjawab soalan-soalan peperiksaan awam. Hal ini sudah pasti mengundang masalah kepada murid terutamanya dalam proses pembelajaran bahasa kedua. Dari aspek psikolinguistik, murid bukan penutur natif yang kurang berkomunikasi secara lisan dan tulisan menggunakan bahasa kedua, dalam konteks ini bahasa Melayu, pasti menjejaskan pencapaian akademik mereka.

Penguasaan bahasa untuk berkomunikasi merupakan matlamat pengajaran bahasa di sekolah. Untuk mencapai penguasaan bahasa pada tahap yang paling tinggi guru harus memberikan penekanan yang sama rata terhadap keempat-empat kemahiran berbahasa, iaitu mendengar, bertutur, membaca dan menulis. Dari segi amalannya, guru lebih menitikberatkan pengajaran pembacaan dan penulisan untuk meningkatkan prestasi akademik dan sering mengabaikan kemahiran mendengar dan bertutur. Amalan sedemikian tidak wajar dilakukan lebih-lebih lagi kepada murid bukan penutur natif di SJK yang mempelajari bahasa Melayu sebagai bahasa kedua. Pengajaran dan latihan pendengaran perlu diutamakan dan 
diberikan asas yang kukuh sebelum murid-murid diajarkan kemahiran membaca dan menulis.

Dalam konteks pengajaran dan pembelajaran bahasa, murid perlu menguasai kemahiran mendengar untuk membolehkan mereka menguasai kandungan mata pelajaran yang disampaikan oleh guru. Keupayaan mendengar yang baik merupakan kelebihan bagi murid untuk menguasai isi pelajaran yang diajar oleh guru. Keupayaan bertutur pula dapat mempercepat pemahaman murid terutama yang berkaitan dengan komunikasi interpersonal. Pengajaran dan pembelajaran kemahiran ini memerlukan pendekatan yang sesuai terutama apabila berhadapan dengan murid yang mempelajari bahasa Melayu sebagai bahasa kedua kerana di SJK murid bukan penutur natif amat keliru dengan bahasa ibunda, bahasa Inggeris dan bahasa Melayu yang mesti dikuasai. Faktor etnik dan gangguan bahasa ibunda merupakan penyebab utama kedua-dua kemahiran tersebut sukar dikuasai. Apabila kedua-dua aspek ini diabaikan dalam PdPc menyebabkan murid tidak mampu menerima komunikasi melalui kemahiran mendengar dan membaca. Hal ini menyebabkan murid bukan penutur natif tidak dapat menyampaikan komunikasi melalui tulisan kerana guru mengabaikan kedua-dua kemahiran tersebut lebih-lebih lagi di SJK.

Berdasarkan faktor tersebut, kajian ini dijalankan bertujuan untuk mengenal pasti tahap kemahiran mendengar dan bertutur, membaca dan menulis murid bukan penutur natif di SJK dan hubungannya dengan pencapaian akademik. SJK Daerah Kuantan dipilih sebagai lokasi kajian berdasarkan senarai Sekolah Mengikut Kumpulan Jenis dan Negeri oleh Kementerian Pendidikan Malaysia (Mei 2014). Kuantan Pahang merupakan antara 4 Daerah yang mempunyai bilangan SJKC dan SJKT tertinggi di Pahang. Setelah pengkaji menjalankan analisis berdasarkan keputusan UPSR murid bukan penutur natif di Daerah Kuantan bermula dari tahun 2012, 2013 dan 2014 didapati Gred Purata Sekolah (GPS) bagi sekolah SJK didapati menurun. Kajian perlu dilakukan untuk meningkatkan prestasi akademik murid bukan Melayu di sekolah-sekolah tersebut. Walaupun pihak guru menumpukan kemahiran membaca dan menulis di SJK, namun prestasi akademik murid bukan Melayu terus menurun. Usaha untuk mencapai aspirasi negara seperti yang terkandung di dalam Pelan Pembangunan Pendidikan Malaysia (PPPM) (2013 - 2025) sekurang-kurangnya 90\% murid mendapat gred kepujian dalam bahasa Melayu pada peringkat SPM, jurang prestasi antara kumpulan etnik ini perlu ditangani. 


\section{OBJEKTIF KAJIAN}

Kajian ini bertujuan untuk mengenal pasti tahap keseluruhan profesiensi bahasa Melayu murid bukan penutur natif di SJK Daerah Kuantan bagi keempat-empat kemahiran dan untuk menentukan hubungan antara Skor Keseluruhan UPBM_SR dengan pencapaian akademik (Penulisan Bahasa Melayu, Pemahaman Bahasa Melayu dan markah keseluruhan subjek).

Antara persoalan yang dijawab dalam kajian ini termasuklah (i) tahap keseluruhan profesiensi Bahasa Melayu (TKPBM) murid bukan penutur natif di SJK Daerah Kuantan dan (ii) hubungan antara skor keseluruhan UPBM_SR dengan markah Penulisan Bahasa Melayu, Pemahaman Bahasa Melayu dan markah keseluruhan subjek murid bukan penutur natif di Daerah Kuantan.

\section{METODOLOGI KAJIAN}

Kajian ini menggunakan kaedah pengumpulan data secara kuantitatif dengan reka bentuk tinjauan keratan rentas (cross-sectional). Reka bentuk ini dipilih untuk membolehkan data dikumpul secara terus daripada subjek kajian kerana melibatkan individu yang berskala besar. Data dipungut sekali sahaja daripada sampel kajian pada satu-satu masa tanpa meningkatkan kos dan dapat dilakukan dalam masa yang singkat serta generalisasi boleh dibuat terhadap populasi kajian yang lebih besar dengan tepat dan berkesan (Creswell, 2008).

Reka bentuk kajian ini dibahagikan kepada dua fasa, iaitu: Fasa 1 membentuk Ujian Profesiensi Bahasa Melayu(UPBM_SR) dan Tahap Skor UPBM_SR untuk mendapatkan Tahap Keseluruhan Profesiensi Bahasa Melayu (TKPBM) bagi murid bukan penutur natif. Fasa 2 membangunkan borang soal selidik untuk mendapatkan demografi murid, dan pemboleh ubah pencapaian akademik murid. Dalam fasa ini, penyelidik ingin melihat hubungan antara TKPBM dengan pemboleh ubah kajian seperti yang ditunjukkan pada Rajah 3.

Fasa 1

1. Bina instrumen UPBM_SR dan Tahap Skor UPBM_SR

2. Tentukan TKPBM murid bukan penutur natif

\section{Fasa 2}

1. Bina soal selidik

2. Tentukan hubungan antara TKPBM dengan pencapaian akademik murid bukan penutur natif

Rajah 3 Fasa reka bentuk. 


\section{PERSAMPELAN}

Berdasarkan (Krejcie \& Morgan, 1970) kaedah pemilihan sampel bagi kajian ini ialah persampelan rawak sistematik. Sampel diperoleh dengan memilih unsur secara rawak. Penyelidik mendapatkan senarai kesemua subjek yang berkemungkinan untuk dipilih. Pemilihan data adalah dibuat dengan memilih setiap $\mathrm{m}$ sampel daripada senarai data tersebut (merupakan senarai data sampel yang diperlukan). Cara pengambilan persampelan ini adalah dengan hanya unsur atau bilangan data pertama dipilih secara rawak, manakala bilangan data berikutnya dipilih secara sistematik mengikut suatu pola tertentu. Kaedah ini dilakukan dengan memilih subjek kajian berdasarkan selang. Pengiraan dilakukan dengan cara: senarai data $=3252$, data sampel diperlukan $=414$, maka $\mathrm{k}=8$. Bagi memilih data yang pertama, satu nombor dari $1-8$ dipilih secara rawak. Penyelidik memilih nombor 3, maka nombor seterusnya ialah $3+8=11$ (dan nombor yang seterusnya adalah $11+8,19+8,27+8$ dan seterusnya). Jumlah populasi kajian (murid bukan penutur natif tahap 2 di SJK di Daerah Kuantan adalah seramai 3252 orang.

$$
\text { Formula }=\frac{\text { Bilangan populasi }}{\text { Bil Sampel }} \quad \mathrm{N}=414 \text { orang }
$$

Responden yang dikaji seramai 198 orang (47.1\%) murid lelaki dan 222 orang $(52.9 \%)$ murid perempuan. Sebanyak 268 berbangsa Cina manakala India seramai 146 sahaja kerana SJKT merupakan Sekolah Kurang Murid (SKM). Responden paling ramai dipilih daripada kalangan murid tahun 6, iaitu seramai 334 orang yang telah selesai menjalani peperiksaan UPSR pada tahun tersebut. Bagi memenuhi ruang masa pada masa kutipan data dibuat, pihak sekolah meminta penyelidik memberikan ujian UPBM_SR kepada murid Tahun 6 kerana murid Tahun 5 hanya seramai 61 orang dan murid Tahun 4 seramai 27 orang yang kebanyakan mereka dari SJKT. Responden dipilih daripada murid tahap 2 yang telah menguasai keempat-empat kemahiran dalam BM, iaitu kemahiran mendengar, menulis, membaca, dan bertutur. Pemilihan responden dibuat oleh guru yang mengajar Bahasa Melayu di sekolah tersebut. 


\section{INSTRUMEN KAJIAN}

Instrumen yang digunakan ialah Ujian Profesiensi Bahasa Melayu Sekolah Rendah (UPBM_SR) yang terdiri daripada Ujian Mendengar, Ujian Bertutur, Ujian Membaca dan Ujian Menulis. Keempat-empat instrumen dibangunkan dengan proses adaptasi dan penyesuaian seperti Rajah 4. Tahap Skor UPBM_SR bagi setiap Ujian, iaitu Tahap Skor Ujian Mendengar, Tahap Skor Ujian Bertutur, Tahap Skor Ujian Membaca, Tahap Skor Ujian Menulis dan Tahap Skor Keseluruhan UPBM_SR juga telah melalui proses seperti Ujian Profesiensi UPBM_SR.

Pembangunan instrumen, UPBM_SR melalui lima peringkat, iaitu peringkat persediaan ujian, pemeriksaan dan pengukuran, analisis ujian,

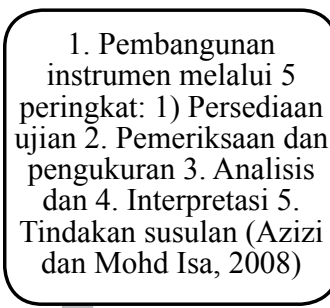

2. Item dibangunkan diadaptasi dan penyesuaian berdasarkan Semakan Semula Domain Kognitif Taksonomi Bloom oleh Anderson dan Krathwohi (2001)

3. Petikan Ujian Mendengar dan Ujian Membaca menggunakan Fomula Kebolehbacaan (Khadijah Rohani 2001) dan Ujian Kloz

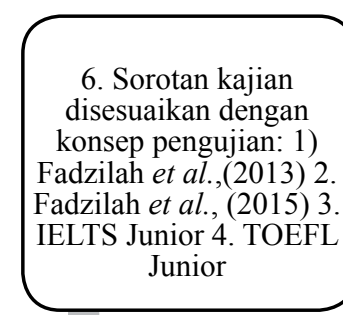

5. Rujukan: 1. Buku teks BM SJK, 2. Majalah, 3.

Buku rujukan 4. CEF,

5. Preparation Manual English Language Learning Standards

4. Dibangunkan berdasarkan kerangka UKBM, DSKP BM SJK (Tahap 2) Ujian Bertutur PT3, Ujian Lisan (SPM), Peperiksaan Bertulis UPSR4.

Rajah 4 Pembangunan, adaptasi dan penyesuaian instrumen UPBM_SR dan Tahap Skor UPBM_SR. 
interpretasi dan tindakan susulan (Azizi \& Mohd Isha, 2008). Pertama, peringkat persediaan ujian, UPBM_SR dibangunkan berdasarkan kerangka Ujian Kecekapan Bahasa Melayu (UKBM), rujukan silibus-silibus Bahasa Melayu Lembaga Peperiksaan, Kementerian Pendidikan Malaysia (KPM), rujukan format soalan-soalan kefahaman Ujian Profesiensi Bahasa Inggeris TOEFL Junior dan IELTS Junior. Kedua peringkat pemeriksaan dan pengukuran, menggunakan Formula Kebolehbacaan Petikan Bahasa Melayu Khadijah Rohani (2001) dan Ujian Kloz untuk mengukur tahap kesukaran atau kebolehbacaan bahan setiap teks petikan bacaan bagi Ujian Mendengar dan Ujian Membaca UPBM_SR. Ketiga, analisis ujian, kedua-dua proses dijalankan melalui kajian rintis untuk memastikan kesahan dan kebolehpercayaan teks petikan. Kedua-dua formula juga untuk melihat kesesuaian teks dari segi pemilihan perkataan bahasa Melayu kepada murid bukan penutur natif di SJK dan kesesuaian umur bacaan (Juntos, 2002). Keempat, peringkat interpretasi hasil kajian rintis. Kelima, tindakan susulan. Instrumen kajian yang dibangunkan dirujuk kepada ahli panel penilai.

\section{Ujian Mendengar UPBM_SR}

Kutipan data Ujian Mendengar dijalankan secara kuantitatif. Data dikumpul menggunakan kertas jawapan murid berbentuk aneka pilihan. Data Ujian mendengar diperoleh menggunakan komponen Ujian Mendengar UPBM_SR dan berdasarkan prosedur yang diperjelas. Jumlah markah Ujian Mendengar yang diperoleh diperingkatkan menggunakan Tahap Skor UPBM_SR dan Pemeringkatan Tahap Skor UPBM_SR.

\section{Ujian Bertutur UPBM_SR}

Ujian Bertutur UPBM_SR dilaksanakan bertujuan untuk mengenal pasti tahap kefasihan bertutur murid bukan penutur natif. Murid diharapkan dapat menyampaikan maklumat dengan sebutan, intonasi, menggunakan bahasa yang gramatis dan bermakna semasa berkomunikasi dalam pelbagai situasi.

\section{Ujian Membaca UPBM_SR}

Ujian Membaca dilaksanakan untuk mengenal pasti tahap kelancaran membaca, memahami perkataan sukar, menaakul dan kebolehan murid 
memindahkan maklumat daripada pelbagai bahan bacaan untuk menjawab soalan kefahaman daripada petikan yang disediakan.

\section{Ujian Menulis UPBM_SR}

Ujian Menulis UPBM_SR dilaksanakan bertujuan untuk mengenal pasti tahap kemahiran menulis murid bukan penutur natif. Murid dapat menulis karangan menepati kehendak soalan, menggunakan bahasa yang gramatis dari segi morfologi dan sintaksis. Penggunaan tanda baca dan ejaan yang betul dan penggunaan kosa kata yang luas dan tepat.

\section{Tahap Skor UPBM_SR}

Tahap skor dan skor rubrik untuk UPBM_SR dibina dengan menyemak dan mengadaptasi rubrik yang sedia ada. Tahap Skor dan rubrik untuk UPBM_SR akan menentukan skor murid bukan penutur natif dalam UPBM_SR. Oleh itu, penyelidik menggunakan skor mendengar, bertutur, membaca dan menulis dan skor keseluruhan UPBM_SR untuk mengukur tahap profesiensi responden dalam bahasa Melayu.

\section{Soal Selidik}

Soal selidik dalam Bahagian A yang mengandungi informasi demografi dan Bahagian B berkaitan dengan Pencapaian Akademik murid telah digunakan kerana kedua-dua bahagian ini dapat digunakan untuk pengumpulan data kuantitatif daripada responden yang banyak. Bahagian A berkaitan dengan maklumat diri responden dan bahagian ini telah dibangunkan oleh penyelidik untuk mendapatkan maklumat tentang latar belakang responden. Dalam Bahagian B, responden diminta untuk mencatatkan markah Peperiksaan Pertengahan Tahun bagi subjek Bahasa Melayu Penulisan, Bahasa Melayu Pemahaman dan Markah Keseluruhan. Oleh sebab responden merupakan murid bukan penutur natif dari SJK dan berumur tidak lebih daripada 12 tahun, mereka telah dibimbing untuk melengkapkan soal selidik terutama yang berkaitan dengan pengisian markah peperiksaan.

\section{Kesahan Instrumen Kajian}

Pengukuran kesahan ujian dan soal selidik telah dibuat dengan teliti untuk memastikan tahap pencapaian dan kecekapan bahasa tepat dinilai. Tahap 
kesahan yang tinggi dapat membantu mengukur keupayaan sebenar murid dalam ujian (Mohamad Majid, 2009). Kedua-dua ujian dan tahap skor UPBM_SR telah dibina melalui pembangunan, adaptasi dan penyesuaian. Untuk memastikan kesahan muka dan kesahan kandungan, alat kajian juga telah disemak oleh ahli panel yang pakar dalam bidang yang berkaitan.

\section{Kajian rintis}

Sebanyak 40 orang murid tahap 2 di SJK telah dipilih untuk menduduki Ujian UPBM_SR dan melengkapkan soal selidik. Responden dipilih daripada kalangan murid bukan penutur natif Tahun 5. Tahap kebolehpercayaan UPBM_SR adalah tinggi setelah penyelidik membuat penambahbaikan dalam keempat-empat ujian, iaitu Ujian Mendengar, Ujian Bertutur, Ujian Membaca dan Ujian Menulis UPBM_SR dan berbincang tentang alat kajian dengan guru yang mengajarkan Bahasa Melayu di SJK. Tahap kebolehpercayaan soal selidik berdasarkan Cronbach Alpha ialah 0.7. Nilai keseluruhan ialah 0.94 . Hal ini menunjukkan soal selidik tersebut mempunyai binaan yang baik, mudah difahami dan sesuai untuk digunakan kepada responden.

\section{DAPATAN KAJIAN}

Dalam konteks kajian ini, dapatan kajian berdasarkan soalan kajian yang dinyatakan di atas.

\section{Tahap Keseluruhan Profesiensi Bahasa Melayu Murid Bukan Penutur Natif}

Skor Keseluruhan UPBM_SR merupakan hasil daripada jumlah kesemua markah yang diperoleh setelah responden menduduki keempat-empat Ujian Profesiensi Bahasa Melayu (UPBM_SR), iaitu Ujian Mendengar UPBM_SR, Ujian Bertutur UPBM_SR, Ujian Membaca UPBM_SR dan Ujian Menulis UPBM_SR. Kemudian Skor Keseluruhan UPBM_SR diperingkatkan berdasarkan Tahap Skor Keseluruhan UPBM_SR untuk menentukan Tahap Keseluruhan Profesiensi Bahasa Melayu (TKPBM) responden. Tahap 1 merupakan tahap paling rendah. Purata markah yang diperoleh antara (1 hingga 50), manakala Tahap 8 merupakan tahap tertinggi. Purata markah bagi tahap ini adalah antara (351 hingga 400). 
Hasil dapatan menunjukkan masih terdapat seramai 122 orang responden atau mewakili $29.4 \%$ yang memperoleh tahap lemah bagi keempat-empat kemahiran dalam Bahasa Melayu terutama kemahiran menulis. Responden yang memperoleh Tahap 1 hingga Tahap 3 dikategorikan sebagai lemah. Namun begitu, tiada responden yang mendapat Tahap 1 (sangat terbatas). Tahap 4 dan Tahap 5 pula dikategorikan sebagai tahap sederhana. Responden yang mendapat Tahap 4 (sederhana profesien) seramai 101 orang atau $24.4 \%$ dan majoriti responden kajian mencapai Tahap 5, iaitu (hampir profesien) bagi kecekapan Bahasa Melayu dengan peratusan 29.0\% (120 orang). Responden yang mencapai Tahap 6 (profesien), sebanyak 62 orang atau $15.0 \%$ dan responden yang mencapai Tahap 7 (lebih profesien) hanya sebanyak 9 orang atau $2.2 \%$ dan tiada responden yang mencapai Tahap 8 (paling profesien) dalam kajian ini. Jadual 2 di bawah menunjukkan taburan tahap profesiensi Bahasa Melayu responden.

Jelasnya, tahap keseluruhan profesiensi Bahasa Melayu murid bukan penutur natif adalah pada tahap sederhana profesien. Hanya 71 orang responden atau $17.2 \%$ yang menguasai keempat-empat kemahiran pada kategori cemerlang.

Jadual 2 Taburan Tahap Keseluruhan Profesiensi Bahasa Melayu (TKPBM) $(\mathrm{N}=414)$.

\begin{tabular}{clcc}
\hline \hline Tahap & $\begin{array}{c}\text { Bilangan } \\
\text { Responden }(\boldsymbol{n})\end{array}$ & $\begin{array}{c}\text { Peratusan } \\
(\mathbf{\%})\end{array}$ \\
\hline 1 & Sangat terbatas & 0 & 0.0 \\
2 & Terbatas & 25 & 6.0 \\
3 & Sangat terhad & 97 & 23.4 \\
4 & Sederhana profesien & 101 & 24.4 \\
5 & Hampir profesien & 120 & 29.0 \\
6 & Profesien & 62 & 15.0 \\
7 & Lebih profesien & 9 & 2.2 \\
8 & Paling profesien & 0 & 0.0 \\
\hline & Jumlah & 414 & 100.0 \\
\hline
\end{tabular}

(Sumber: Nora'azian Nahar (2018). Tahap Profesiensi Bahasa Melayu dan Hubungannya dengan Status Sosioekonomi, Motivasi Belajar dan Pencapaian Akademik dalam kalangan Murid Bukan Penutur Natif.] 
Jadual 3 Korelasi antara Skor Keseluruhan UPBM_SR dengan Markah Penulisan Bahasa Melayu, Markah Pemahaman Bahasa Melayu dan Markah Keseluruhan Subjek murid bukan penutur natif di SJK Daerah Kuantan, Pahang.

\begin{tabular}{|l|l|c|c|c|c|}
\hline \multicolumn{2}{|l|}{ Pemboleh ubah } & $\mathbf{1}$ & $\mathbf{2}$ & $\mathbf{3}$ & $\mathbf{4}$ \\
\hline 1. & Skor Keseluruhan UPBM_SR & 1 & & & \\
2. & Markah Penulisan BM & $.58^{* *}$ & 1 & & \\
3. & Markah Pemahaman BM & $.65^{* *}$ & $.78^{* *}$ & 1 & \\
4. & Markah Keseluruhan Subjek & $.66^{* *}$ & $.84^{* *}$ & $.87^{* *}$ & 1 \\
\hline
\end{tabular}

$* *$ Korelasi signifikan, $p<.01$

[Sumber: Nora'azian Nahar (2018). Tahap Profesiensi Bahasa Melayu dan Hubungannya dengan Status Sosioekonomi, Motivasi Belajar dan Pencapaian Akademik dalam kalangan Murid Bukan Penutur Natif.]

Hubungan antara Skor Keseluruhan UPBM_SR dengan Pencapaian Akademik (Penulisan Bahasa Melayu, Pemahaman Bahasa Melayu dan Markah Keseluruhan Subjek).

Pemboleh ubah yang dipilih dalam kajian ini ialah mata pelajaran Penulisan Bahasa Melayu, Pemahaman Bahasa Melayu dan Peratus bagi keseluruhan markah dalam Peperiksaan Pertengahan Tahun murid bukan penutur natif di SJK. Untuk mencapai objektif kedua bagi kajian ini, tiga soalan kajian telah diformulasi, dan ketiga-tiga soalan kajian berkenaan telah menjalani analisis korelasi hasil darab momen Pearson bagi menjawab soalan tersebut.

\section{Hubungan antara Skor Keseluruhan UPBM_SR dengan Markah BM-Penulisan Murid Bukan Penutur Natif di SJK Daerah Kuantan}

Analisis korelasi hasil darab momen Pearson telah dilaksanakan bagi menentukan perkaitan antara skor keseluruhan UPBM_SR dengan markah Penulisan Bahasa Melayu murid bukan penutur natif di SJK Daerah Kuantan. Semua andaian berkaitan pelaksanaan analisis korelasi hasil darab momen Pearson telah disemak dan tiada pelanggaran dikesan. Analisis mendapati, perkaitan antara pemboleh ubah berkenaan adalah signifikan, $r(412)=0.58, p<.001$. Hal ini menunjukkan, adanya perkaitan antara skor keseluruhan UPBM_SR dengan markah Penulisan Bahasa Melayu murid bukan penutur natif di SJK Daerah Kuantan, dan kekuatan perkaitan antara kedua-dua pemboleh ubah berkenaan adalah besar berdasarkan interpretasi perkaitan Cohen (1988). 


\section{Hubungan antara Skor Keseluruhan UPBM_SR dengan Markah Pemahaman Bahasa Melayu Murid Bukan Penutur Natif di SJK Daerah Kuantan}

Analisis korelasi hasil darab momen Pearson telah dilaksanakan bagi menentukan perkaitan antara skor keseluruhan UPBM_SR dengan markah Pemahaman Bahasa Melayu murid bukan penutur natif di SJK Daerah Kuantan, Pahang. Semua andaian berkaitan pelaksanaan analisis korelasi hasil darab momen Pearson telah disemak dan tiada pelanggaran dikesan. Analisis mendapati, perkaitan antara pemboleh ubah berkenaan adalah signifikan, $r(412)=0.65, p<.001$. Hal ini menunjukkan, adanya perkaitan antara skor keseluruhan UPBM_SR dengan markah BM-Pemahaman murid bukan penutur natif di SJK Daerah Kuantan dan kekuatan perkaitan kedua-dua pemboleh ubah berkenaan adalah besar berdasarkan interpretasi perkaitan Cohen (1988).

\section{Hubungan antara Skor Keseluruhan UPBM_SR dengan Markah Keseluruhan Subjek Murid Bukan Penutur Natif di SJK Daerah Kuantan}

Analisis korelasi hasil darab momen Pearson telah dilaksanakan bagi menentukan perkaitan antara skor keseluruhan UPBM_SR dengan markah keseluruhan subjek murid bukan penutur natif di SJK Daerah Kuantan. Semua andaian berkaitan pelaksanaan analisis korelasi hasil darab momen Pearson telah disemak dan tiada perlanggaran dikesan. Analisis mendapati, perkaitan antara pemboleh ubah berkenaan adalah signifikan, $r(412)=0.66, p<.001$. Hal ini menunjukkan, adanya perkaitan antara skor keseluruhan UPBM_SR dengan markah keseluruhan subjek murid bukan penutur natif di SJK Daerah Kuantan dan kekuatan perkaitan kedua-dua pemboleh ubah berkenaan adalah besar berdasarkan kepada interpretasi perkaitan Cohen (1988).

Daripada analisis didapati hubungan antara Skor Keseluruhan UPBM_SR dengan ketiga-tiga pemboleh ubah, iaitu Penulisan Bahasa Melayu, Pemahaman Bahasa Melayu dan Markah Keseluruhan Subjek berdasarkan Interpretasi Perkaitan Cohen (1988) adalah besar kerana keempat-empat kemahiran tersebut menentukan pencapaian akademik murid bukan penutur natif. 


\section{PERBINCANGAN}

Berdasarkan kajian yang telah dilaksanakan, dapatan telah memberikan gambaran yang jelas tentang fenomena yang dikaji.

\section{Tahap Penguasaan Keempat-empat Kemahiran Bahasa Murid di SJK}

Tahap keseluruhan profesiensi mendengar, bertutur, membaca dan menulis murid bukan penutur natif ialah Tahap 5 (hampir profesien). Kajian terdahulu membuktikan peranan guru amat penting dalam proses membina kemahiran berbahasa kedua. Pembelajaran bahasa kedua perlu dilakukan dengan giat dan murid bukan penutur natif perlu melakukan pembetulan baik dari segi kemahiran bacaan mahupun tulisan. Dalam proses pemerolehan bahasa kedua suatu kewajipan bagi murid bukan penutur natif melakukan latih tubi untuk mengaplikasikan lakuan baharu menggunakan sistem bahasa dan teknik yang betul terutama kemahiran membaca dan menulis. Oleh sebab, murid bukan penutur natif tidak menguasai kemahiran membaca dan menulis dalam bahasa ibunda ditambah dengan kekeliruan dari segi aksara (bahasa Mandarin menggunakan Kai Ti manakala bahasa Tamil menggunakan Sellinam) serta kepelbagaian dialek menyebabkan murid mendapat markah yang sederhana dalam bahasa ibunda juga. Hal ini kerana murid terpaksa mempelajari banyak perkara yang berbeza di SJK termasuk bahasa ibunda, bahasa Inggeris dan bahasa Melayu.

Usaha yang padu perlu dilakukan oleh pihak sekolah terutamanya guru-guru yang mengajar bahasa Melayu untuk meningkatkan penguasaan kemahiran membaca dan menulis dalam kalangan murid bukan penutur natif di SJK. Bagi meningkatkan kemahiran membaca, guru digalakkan memberikan ujian ejaan setiap kali sebelum memulakan kelas dan memperkenalkan suku kata dalam bahasa Melayu. Semasa murid mengeja perkataan yang diberikan oleh guru, murid akan mendengar dengan teliti sebutan suku kata daripada guru. Sebelum memulakan ejaan murid juga digalakkan untuk membaca petikan dan menghafal perkataan sebelum diberikan ejaan. Murid dapat menguasai bahasa Melayu apabila mereka mendengar dengan teliti perkataan yang disebut oleh guru, kemudian menyebut suku kata sebelum mengeja dan seterusnya membunyikan atau membaca dan menulis perkataan yang diberikan. Dalam sistem ejaan keempat-keempat kemahiran perlu diaplikasikan. Guru-guru boleh merakam bacaan murid dan memperdengarkan bacaan kepada kelas. Murid-murid boleh diminta menyebut berulang kali perkataan yang salah sebutannya hingga betul. Guru juga boleh bersoal jawab dengan murid 
seperti mengadakan kuiz, mencari makna kata dan mempelbagaikan aktiviti bagi meningkatkan keempat-empat kemahiran mengikut tahap murid.

Kemahiran menulis dianggap kemahiran paling kritikal di SJK kerana terdapat $65.2 \%$ responden yang tidak mahir menulis menggunakan bahasa Melayu walaupun telah menamatkan peperiksaan UPSR tahun 6. Guru perlu memberikan tumpuan terhadap proses mengarang, iaitu merancang dan merangka, dan juga penghasilan karangan, iaitu menulis dan menyunting. Menulis merupakan tahap paling tinggi dalam proses menghasilkan sebuah karangan. Profesiensi tertinggi ini tidak hanya melibatkan aspek teknikal dan mekanikal semata-mata, tetapi penulisan turut melibatkan penggemblengan aspek psikologi dan kognitif. Pengetahuan kandungan pedagogi perlu dihayati kerana tubuh ilmu dan dicerakinkan menggunakan strategi yang sesuai dan terancang agar matlamat yang dikehendaki tercapai. Guru-guru BM juga perlu menggunakan strategi pembelajaran bahasa yang mantap terutama bagi pengajaran karangan dalam bahasa kedua supaya pemerolehan, penyimpanan, dan pemerolehan semula serta penggunaan maklumat dapat dijana bagi mempertingkatkan pencapaian dan penguasaan profesiensi menulis. Kombinasi keempat-empat faktor utama, iaitu isi atau idea teknik penghujahan, profesiensi berbahasa dan keberkesanan dalam menghasilkan sebuah karangan yang bermutu tinggi perlu dikuasai oleh guru di SJK bagi meningkatkan tahap profesiensi BM sekali gus meningkatkan pencapaian akademik.

Krashen dalam Hipotesis kedua, iaitu Hipotesis Pemerolehan dan Pembelajaran (1981) menjelaskan kompetensi menguasai bahasa kedua melalui pemerolehan bukan pembelajaran. Peranan penting perlu dimainkan oleh ibu bapa untuk memberikan pendedahan bahasa kedua kepada anak-anak yang berumur bawah 13 tahun supaya pemerolehan berlaku secara natural. Selain itu, pihak sekolah juga perlu menyediakan kemudahan untuk murid bukan penutur natif bagi meningkatkan prestasi akademik secara tidak formal. Peranan pihak sekolah boleh memperdengarkan lagu-lagu dalam bahasa Melayu pada waktu sebelum masuk kelas, waktu rehat, atau sebelah petang sebagai halwa telinga supaya murid bukan penutur natif sentiasa mendengar sebutan, perkataan dalam bahasa Melayu dengan jelas. Kemahiran mendengar yang berjaya memerlukan aktiviti yang interaktif daripada sumber multimedia. Latihan perlu bermula dengan mendengar teks yang mudah, kemudian diikuti dengan aktiviti yang memberikan penumpuan kepada proses mendengar. Tajuk pembelajaran mendengar perlu dipilih yang dekat di hati murid atau berkaitan dengan persekitaran murid. Pemilihan perkataan dalam petikan 
Ujian Mendengar juga perlu dipilih daripada senarai kosa kata yang disyorkan dalam DSKP bahasa Melayu untuk SJK. Guru perlu melatih murid menggunakan perkataan baharu yang mereka pelajari agar murid dapat mengingati perkataan tersebut. Sebelum rakaman diperdengarkan, murid perlu diberikan kertas soalan supaya mereka lebih bersedia dan memahami petikan dengan baik. Soalan yang disediakan boleh dijadikan panduan untuk murid mendengar, memudahkan mereka mencari kata kunci, isi penting dan juga supaya mereka memberikan tumpuan kepada perkara yang didengarnya.

Bagi kemahiran bertutur masih terdapat sebanyak 55.7\% responden kurang fasih dalam kemahiran bertutur menggunakan bahasa Melayu di SJK. Antara langkah yang boleh diambil bagi memperbaik kemahiran bertutur termasuklah keperluan kepada murid SJK untuk berkomunikasi dan berinteraksi dengan guru, rakan penutur natif, pekerja, penjual, dan jiran tetangga yang berketurunan Melayu. Selain itu, aktiviti yang tidak melibatkan silibus di sekolah banyak memberi ruang kepada mereka untuk berkomunikasi secara tidak formal dengan penutur natif. Aktiviti ini seterusnya dapat menambah kosa kata, dan mengenali sebutan. Kemahiran bertutur berlaku secara spontan dan penutur jati dapat memperbaik sebutan ketika mereka berkomunikasi secara terus. Jika murid dapat mempraktikkan penggunaan perkataan yang sesuai dengan situasi semasa berkomunikasi dan membaca nescaya murid bukan penutur natif dapat mengenali perkataan baharu, malah usaha ini dapat membantu murid lebih mengingat maknanya. Murid juga boleh merujuk senarai perbendaharaan perkataan apabila berhadapan dengan perkataan baharu yang ditemukan semasa berkomunikasi. Murid akan memperoleh nilai tambah sekiranya mereka dapat membaca bahan bacaan dalam bahasa Melayu, menggunakan perkataan tersebut dan membiasakan penggunaannya serta mempraktikkan perkataan yang baru yang dipelajari untuk menulis karangan yang berkaitan.

Dalam usaha pemerolehan bahasa kedua, murid bukan penutur natif mesti mempraktikkannya dalam kehidupan seharian. Semasa berkomunikasi mereka akan mendengar dengan teliti dan cuba meneka makna perkataan baharu sama ada berdasarkan keseluruhan ayat, frasa, perenggan ataupun cerita. Murid bukan penutur natif perlu kerap berkomunikasi menggunakan bahasa Melayu untuk membantu mereka memahami sesuatu perkataan dengan lebih mudah. Strategi ini mampu membuatkan murid bukan penutur natif mengingati makna perkataan baharu oleh sebab murid melihat penggunaannya dalam konteks sebenar. 
Hal ini berupaya membantu murid menjadi lebih peka untuk menuturkan bahasa Melayu dengan betul sekali gus dapat meningkatkan pencapaian akademik mereka. Murid yang menguasai kemahiran lisan dapat mengaplikasinya dalam penulisan.

Dalam pembelajaran bahasa di sekolah, acara kebudayaan Melayu seperti pertandingan bercerita, syarahan, pidato, perbahasan, ucapan, drama, nyanyian, pementasan seni budaya juga menggalakkan murid bukan penutur natif menyebut perkataan dalam bahasa Melayu semasa menyertai pertandingan tersebut. Guru dapat membetulkan sebutan yang kurang jelas, memilih perkataan yang bertepatan dengan situasi dan dapat menggalakkan murid menguasai kemahiran mendengar dan bertutur. Aktiviti tersebut secara tidak langsung dapat memperbaik kelemahan murid bukan natif dari segi sebutan, gaya persembahan, nada, intonasi, dan keyakinan diri murid bertutur menggunakan bahasa Melayu standard. Namun begitu, kesalahan sebutan itu bukanlah tanda kelemahan murid berkenaan, tetapi memperlihatkan kelemahan dalam kaedah pembelajaran bahasa. Hakikatnya kemahiran mendengar dan bertutur ialah cara berkomunikasi tanpa sebarang latihan formal, kanak-kanak secara automatik dapat menguasai perkataan dan mengolahnya menjadi wacana untuk berhubung. Latihan secara formal pula akan memperbaik, meneguhkan dan menggayakan kebolehan bertutur mereka lagi (Gleason \& Ratner, 2013).

\section{Hubungan Tahap Profesiensi dengan Pencapaian Akademik}

Hasil dapatan menunjukkan keempat-empat tahap kecekapan bahasa Melayu murid bukan penutur natif pada tahap sederhana disebabkan sikap masyarakat yang tidak mendukung kedaulatan bahasa Melayu sebagai bahasa rasmi negara. Mereka tidak mahu bertutur menggunakan bahasa Melayu kerana menganggap bahawa bahasa Melayu tidak berkepentingan dalam kehidupan mereka. Bahasa Melayu hanya digunakan semasa pembelajaran bahasa Melayu di sekolah dan mereka mempelajarinya semata-mata untuk lulus dalam peperiksaan bagi melayakkan mereka mendapatkan sijil pada peringkat SPM. Bahasa Melayu juga tiada keperluan dalam kehidupan seharian kerana apabila pulang ke rumah mereka akan menggunakan bahasa ibunda atau bahasa Inggeris. Dalam kerjaya pula kebanyakan murid akan memilih untuk melanjutkan pelajaran ke luar negara atau di universiti swasta yang menggunakan bahasa Inggeris sebagai bahasa pengantar. Kelunturan penggunaan bahasa Melayu ini merupakan 
faktor yang menyebabkan pencapaian akademik di SJK semakin menurun. Akibat ketidakcekapan murid mendengar dan ketidakfasihan murid dalam pertuturan, menyebabkan tidak berlaku komunikasi lisan. Keadaan ini ditambah pula dengan ketidaklancaran murid membaca dalam bahasa Melayu menyebabkan masalah paling kritikal dalam penulisan akibat ketidakmahiran murid bukan penutur natif dalam kemahiran menjawab soalan peperiksaan yang kesemuanya menghendaki murid menjawab secara bertulis. Dapatan ini jelas menunjukkan bahawa hubungan yang besar antara tahap profesiensi dengan pencapaian akademik kerana penguasaan kemahiran lisan dan bertulis penentu kepada kecemerlangan bahasa Melayu seseorang murid.

Pemboleh ubah yang dikaji dalam kajian ini ialah (Penulisan bahasa Melayu, Pemahaman Bahasa Melayu dan markah bagi kesemua subjek yang diajar di SJK. Ketiga-tiga pemboleh ubah yang dikaji menunjukkan hubungan yang signifikan. Antara tiga pemboleh ubah tersebut perkaitan paling besar yang ditunjukkan berdasarkan interpretasi Cohen (1988) adalah antara skor keseluruhan UPBM_SR dengan markah bagi kesemua subjek. Dapatan ini menunjukkan walaupun keseluruhan subjek diajar menggunakan bahasa ibunda kecuali Bahasa Melayu tetapi penguasaan kemahiran membaca dan menulis dalam bahasa kedua dapat diaplikasikan untuk menjawab UPBM_SR. Hal ini juga disebabkan responden telah diberikan latih tubi menjawab soalan BM-Pemahaman dan BM-Penulisan sebelum menduduki peperiksaan pada peringkat sekolah. Aspek yang diuji dalam UPBM_SR terutama Ujian Membaca dan Ujian Menulis mempunyai format yang hampir sama. Dapatan selari dengan kajian Fakeye (2014) di Nigeria. Semakin tinggi tahap profesiensi Bahasa Inggeris yang diperoleh dalam peperiksaan bahasa kedua, semakin tinggi pencapaian akademik pelajar.

Pencapaian akademik yang kedua besar menunjukkan kekuatan perkaitan antara skor keseluruhan UPBM_SR dengan Pemahaman Bahasa Melayu. Perkaitan besar antara kedua-dua pemboleh ubah tersebut adalah kerana terdapat keselarian antara aspek yang diuji dalamUPBM_SR dengan format baharu UPSR. Aspek yang diuji ialah penggunaan kata, perkataan sama maksud, kesalahan tatabahasa dan soalan kefahaman petikan. Murid perlu menjawab soalan pemahaman berdasarkan petikan yang diberi dan mengisi tempat kosong dengan jawapan yang paling sesuai, memilih ayat yang sama maksud, dan memilih ayat yang gramatis. Pada Bahagian B pula, murid perlu menjawab soalan berbentuk subjektif aneka pilihan. Soalan KBAT melibatkan aras mengaplikasikan, menganalisis, menilai, 
dan mencipta, juga terdapat dalam kedua-dua instrumen berdasarkan Taksonomi Bloom yang diperbaharui oleh Anderson dan Krathwol (2001). Jelasnya, kedua-dua pemboleh ubah saling berkait rapat. Semakin tinggi pencapaian BM-Pemahaman murid di SJK, semakin tinggi skor markah diperoleh dalam keempat-empat Ujian UPBM_SR. Murid yang cemerlang akademik dapat mengaplikasikan kemahiran lisan kerana melalui komunikasi lisan murid dapat mengaplikasikan kemahiran bacaan dan menjawab soalan-soalan bertulis dengan cemerlang.

Keselarian antara skor keseluruhan UPBM_SR dengan Penulisan Bahasa Melayu juga didapati menunjukkan perkaitan yang besar. Hubungan ini menunjukkan murid yang mendapat markah cemerlang dalam BM-Penulisan semasa Peperiksaan Pertengahan Tahun mampu mendapat sekurang-kurangnya Tahap 6 (Profesien) dan Tahap 7 (Lebih Profesien) dalam UPBM_SR. Murid yang menguasai kemahiran membaca dan menulis dalam bahasa pertama dapat menjawab keempat-empat ujian UPBM_SR dengan skor keseluruhan yang tinggi. Mereka menggunakan kemahiran menguasai bahasa pertama atau bahasa ibunda masingmasing untuk menghasilkan penulisan dalam bahasa Melayu. Murid di SJK menggunakan strategi menghafal rumus-rumus dalam bahasa kedua dan menggunakan semula dalam peperiksaan. Selain itu, murid di SJK menggunakan kaedah terjemahan untuk menghasilkan karangan. Kajian ini selari dengan kajian (Punitha et al., 2017).

Masalah utama yang dapat dikesan bagi kemahiran menulis daripada kajian ini ialah murid bukan penutur natif bukan sahaja keliru dengan huruf dan bentuk yang hampir sama dalam bahasa Melayu, malah mereka amat keliru dengan penggunaan aksara dalam Mandarin menggunakan "Kai Ti" dan dalam bahasa Tamil menggunakan Sellinam. Oleh hal yang demikian, kerja karang-mengarang menjadi semakin rumit untuk dizahirkan oleh murid yang terpaksa mempelajari banyak bahasa kerana berlaku pemindahan terbalik daripada bahasa pertama. Dapatan kajian ini mengesahkan bahawa Hipotesis Monitor (2007) Krashen adalah benar. Peranan filter, organizer dan monitor dalam pembelajaran bahasa kedua melalui hafalan. Hampir 90\% jawapan penulisan karangan yang ditulis oleh responden ialah karangan yang dihafal untuk menjawab soalan BMPenulisan dalam peperiksaan UPSR yang lalu. Majoriti murid terpengaruh dengan bahasa ibunda dari segi ejaan, sebutan dan penggunaan perkataan dalam penulisan dan bacaan teks bahasa kedua. Dalam Hipotesis ketiga, iaitu Hipotesis Monitor (Monitor Hypothesis) (2007) Krashen menegaskan bahawa terdapat tiga faktor dalaman yang beroperasi dalam 
minda manusia ketika menguasai bahasa kedua, iaitu filter, organizer dan monitor. Filter berfungsi untuk menapis bahasa yang didengar, organizer mengatur bahasa yang ditapis oleh filter dan monitor bertindak memproses maklumat untuk membentuk ayat-ayat purna bentuk semasa murid bukan penutur natif menulis dalam bahasa kedua. Kajian selari dengan dapatan Muhammad Saiful et al., (2012) dan Noor Habsah Ali, (2018).

Jelasnya, kesemua pemboleh ubah yang dipilih dalam kajian ini menunjukkan perkaitan yang besar dengan tahap kemahiran mendengar, bertutur, membaca dan menulis murid bukan penutur natif di SJK. Pencapaian akademik hanya dapat ditingkatkan jika murid cekap mendengar, fasih bertutur, lancar membaca dan mahir menulis dalam bahasa pertama mahupun bahasa kedua. Dapatan kajian juga mengesahkan Hipotesis Monitor (2007) oleh Krashen adalah benar kerana murid yang kurang kemahiran komunikasi ternyata lemah pencapaian akademik kerana pembelajaran bahasa kedua dilakukan secara hafalan.

\section{Impak kajian}

Dapatan kajian ini penting untuk membantu pihak Kementerian Pendidikan Malaysia (KPM), membuat justifikasi berkaitan dengan isu pendidikan bahasa Melayu, iaitu kemahiran lisan, baca dan tulisan dalam kalangan murid di SJK. Penulisan kajian ini sangat baik dan boleh diangkat sebagai sumber ilmu baharu dalam dunia pendidikan bahasa Melayu di sekolah kerana dapatan dapat menerangkan fenomena yang berlaku dalam kalangan murid di SJK. Secara keseluruhannya, dapatan kajian dapat memberikan impak yang baik dalam sistem pendidikan negara bagi tujuan meningkatkan penguasaan murid bukan penutur natif khususnya literasi Bahasa Melayu. Usaha daripada semua pihak perlu dilipatgandakan untuk pencapaian pembangunan kemahiran mendengar, bertutur, membaca dan menulis murid di SJK sekali gus untuk meningkatkan pencapaian akademik. Secara keseluruhan kajian ini merupakan satu pengkajian yang baik dalam skop pendidikan Bahasa Melayu.

\section{KESIMPULAN}

Komunikasi merupakan alat yang sangat berkesan untuk menyampaikan maklumat dan seterusnya mempengaruhi seseorang pendengar. Murid dapat menyampaikan mesej dengan sempurna dan meningkatkan pencapaian akademik apabila dapat menggunakan bahasa Melayu yang 
baik. Keseluruhannya, kajian ini telah berjaya mengenal pasti tahap penguasaan bagi keempat-empat kemahiran, iaitu kemahiran mendengar, bertutur, membaca, dan menulis dalam kalangan murid bukan penutur natif di SJK. Penilaian yang bersepadu dan berterusan pasti menjadikan apresiasi negara menjadi kenyataan untuk melahirkan generasi yang kompeten dalam bahasa Melayu selari dengan Anjakan Kedua Pelan Pembangunan Pendidikan Malaysia (2013 - 2025). Silibus yang selari antara SJK dengan SK juga dapat merapatkan jurang prestasi antara kumpulan etnik di Malaysia. Hasil maklumat kajian lanjutan dapat digunakan oleh pihak yang terlibat dalam perancangan kurikulum kerana murid bukan penutur natif dari SJK akan menyambung pelajaran ke Sekolah Menengah Kebangsaan (SMK) yang menggunakan bahasa Melayu sebagai bahasa pengantar.

Hasil dapatan juga dapat memberikan panduan kepada guru untuk melaksanakan ujian bagi meningkatkan tahap penguasaan kemahiran lisan, membaca dan menulis. Instrumen UPBM_SR boleh digunakan dan diubah suai mengikut kesesuaian responden. Dasar pengujian kecekapan bahasa rasmi negara telah dirintis untuk kegunaan di sekolah rendah jenis kebangsaan dan boleh diperluas kepada populasi yang lebih menyeluruh untuk mendapatkan data yang lebih komprehensif.

\section{RUJUKAN}

Abdul Rasid Jamian. (Mei 2011). Permasalahan Kemahiran Membaca dan Menulis Bahasa Melayu Murid-murid Sekolah Rendah di Luar Bandar. Jurnal Pendidikan Bahasa Melayu (Malay Language Education Journal (MyLEJ), 1(1), 1-12, ISSN: 2180-4842.

Anderson, L.W. \& Krathwohl, D.R. (2001). A Taxonomy for Learning, Teaching and Assessing. New York: Longman Publishing.

Awang Sariyan. (2011). Pendidikan Bahasa Melayu dalam Pembentukan Jati Diri Bangsa: Pengajaran Seni Bahasa Untuk Penghayatan bahasa kepada Pelajar Asing. Kertas kerja dibentangkan di Seminar Bahasa Melayu 2011. Anjuran Persatuan Pendidikan Bahasa Melayu Malaysia, Jabatan Pendidikan Negeri Terengganu dan Dewan Bahasa dan Pustaka Wilayah Timur pada 14-16 Mac 2011.

Azizi Ahmad \& Mohd Isha Awang. (2008). Pengukuran dan Penilaian Pendidikan. Kuala Lumpur: Dewan Bahasa dan Pustaka.

Chew Fong Peng. (2016). Masalah Pembelajaran Bahasa Melayu dalam Kalangan Murid Cina Sekolah Rendah. Jurnal Pendidikan Bahasa Melayu -JPBM (Malay Language Education Journal - MyLEL). 
Cohen, J.W \& Cohen, P. (1988). Statistical Power Analysis for the Behavioral Sciences (2nd edition). Hillsdale, NJ: Lawrence Erlbaun Associates.

Creswell, J.W. (2008). Research Design: Quantitative, And Mixed Methods Approaches. Sage Publications, University of Nebraska, London.

Ellis, Rod. (2008). The Study of Second Language Acquisition. Oxford, UK: Oxford University Press.

Fadzilah Abd Rahman dan Norazlina Mohd Kiram. (2015). Bahasa Melayu sebagai bahasa Negara Bangsa: Kepentingan Melaksanakan Ujian Kecekapan Bahasa Melayu. Mahawangsa, 2(1),15-28.

Gleason, J.B. \& Ratner, N.B. (eds.). (2013). Development of Language. 8th Edition. New York, NY: Routledge.

Hasnalee Tubah \& Zulkifley Hamid. (2011). Pengaruh Demografi terhadap kemahiran membaca dan memahami dalam kalangan murid-murid LINUS. Jurnal Bahasa.

Juntos, H. (2002). Language Testing Option. California: Robert Wood Johnson Foundation.

Kementerian Pendidikan Malaysia. (2013-2015). Pelan Pembangunan Pendidikan Malaysia (PPPP) (Pendidikan Prasekolah hingga Lepas Menengah). Kuala Lumpur: Kementerian Pelajaran Malaysia.

Krashen Stephen D. (1981). Principles and Practice in Second Language Acquisition. English Language Teaching Series. London: Printice-Hall International (UK) Ltd.

Krashen Stephen D. (1985). Second Language Acquisition and Second Language Learning. Oxford: Pergamon Press.

Krashen Stephen D. (2007). Extensive Reading in English as Foreign Language by Adolescents and Young Adults: A Meta-Analysis. International Journal of Foreign Language Teaching, 3(2), 23-29.

Krashen Stephen D. (2013). Second Language Acquisition. Theory, Aplications, and Some Conjectures. New York: Cambridge University Press.

Krejcie, R.V. \& Morgan, D.W. (1970). Determining Sampel Size for Research Activities. Educational and Psychological Measurement. 30-608.

Khadijah Rohani Mohd. Yunus (2001). Kebolehbacaan dalam Buku Teks. Bahan Kursus Penulisan Buku Teks Sekolah Menengah, Bahagian Buku Teks. KPM dan Majlis Buku Kebangsaan Malaysia.

Mohamad Majid Konting. (2009). Kaedah Penyelidikan Pendidikan (Edisi ke-9). Kuala Lumpur: DBP

Muhammad Saiful Haq Hussin, Nik Hafizah Abd Rahman dan Agus Syahrani. (2012). Pengajaran dan Pembelajaran Bahasa Melayu dalam kalangan pelajar Tamil: Kaedah Gabung Bunyi Kata. Jurnal Pendidikan Bahasa dan Satera, 12(1).

Noor Habsah Ali. (Mei, 2018). Strategi Pembelajaran Kemahiran Menulis bahasa Melayu Sebagai Bahasa Kedua dalam Kalangan Pelajar Melanau Daerah Daro. Jurnal Pendidikan Bahasa Melayu - JPBM (Malay Language 
Education Journal - MyLEJ).ISSN: 2180-4842..8(1), 33-41

Noor Zila Md Yusuf. (2015). Bahasa Antara dalam Pembelajaran Bahasa Melayu

Sebagai Bahasa Kedua (Tesis PhD tidak diterbitkan). UPM (FBMK:2015 Bil 50).

Nora'Azian Nahar. (2018). Tahap Profesiensi Bahasa Melayu dan Hubungannya dengan Status Sosioekonomi, Motivasi Belajar dan Pencapaian Akademik Murid Bukan Penutur Natif di Sekolah Jenis Kebangsaan (Tesis PhD tidak diterbitkan). Universiti Putra Malaysia.

Nora'Azian Nahar. (Mei 2018). Tahap Penguasaan Kemahiran Bertutur Bahasa Melayu dalam Kalangan Murid Bukan Penutur Natif. Jurnal Pendidikan Bahasa Melayu - JPBM (Malay Language Education Journal - MyLEJ), 8(1),74-83, ISSN: 2180-4842.

Punitha Vathi Muniandy, Abdul Jalil Othman, Sharir Jamaluddin. (2017). Kesan

Kemahiran Bertutur dalam Bahasa Malaysia Secara Kaedah Pembelajaran Informal dalam kalangan Penutur Asing Dewasa: Satu Pandangan Pembelajaran Berterusan. JuKu Jurnal Kurikulum \& Pengajaran Asia Pasifik, Oktober 2017, Bil. 5, Isu 4.

Roshidah Hassan. (2017). Gaya dan Strategi Pembelajaran Bahasa Melayu dalam Kalangan Pelajar Perancis. GEMA Online Journal of Language Studies 17(1), February 2017.

Sumaiyah Sulaiman, Nik Farhan Mustahpha, Pabiyah Toklubok@ Haji Maming, Wan Muhammad Wan Sulong. (Januari, 2018). Halangan Penguasaan Kemahiran Mendengar Bahasa Arab Sebagai Bahasa Asing. ASEAN Comparative Education Research Journal on Islam and Civilization (ACER-J), 2(1), 1-14, eISSN: 2600-769X.

Wan Dyarudin Wan Mustappa. (Mei, 2017). Keberkesanan Teknik Membaca SQ3R dalam Pengajaran Kefahaman Membaca di Sekolah Menengah. Jurnal Pendidikan Bahasa Melayu - JPBM (Malay Language Education Journal-MyLEJ), 7(1),1-10, .ISSN: 2180-4842.

Zhang, D., \& Goh C.M (2006). Strategy Knowledge and Perceived Strategy Use: Singaporean Students "Awareness of listening and speaking Strategies". Language Awareness, 15(3), 199-219.

Zulkifley Hamid (2014). Faktor Persekitaran Sekolah dan Etnik dalam Perancangan dan Pelaksanaan Program Pendidikan BM di Malaysia. GEOGRAFIA OnlineTM Malaysian Jurnal of Society and Space 10(5), 99-109) C 2014, ISSN 2018-2491).

Diperoleh (received): 27 Mac 2020

Diterima (accepted): 28 Mei 2020 